\title{
M.X. Закирова
}

\section{ОБРАЗ ИМПЕРСКОЙ РОССИИ В ПРОСВЕТИТЕАЬСКОЙ ПОАИТИКЕ ТУРКЕСТАНСКОГО КРАЯ НА РУБЕЖЕ XIX-XX ВВ. (НА ПРИМЕРЕ АЕЯТЕАЬНОСТИ ТУРКЕСТАНСКОГО ОТАЕАА РУССКОГО ГЕОГРАФИЧЕСКОГО ОБЩЕСТВА)}

Аннотация. Статья посвящена истории развития образовательньх программ среднего и высшего образования в Туркестанском крае в конце XIX-начале XX в. 6 контексте имперской политики России. Методологической основой статьи стала концепция ориентализма Э.В. Саида, которая позволила автору обозначить политику Российской империи в сфере образования в Туркестане в контексте «знание сила», что в полной мере отражало интересы российского правительства в организации научных исследований, образования и просвещзения, а также существенно влияло не только на формирование устойчивой политической и экономической стабильности, но и на зарождение образованной прослойки среди населения. В исследовании анализируются проекты развития школ Н.И. Ильминского, идеи К.П. Кауфмана и Н.П. Остроумова, а также рассматривается деятельность Туркестанского отдела Русского географического общества (РГО). Наиболее важные научные исследования ученых Туркестанского отдела РГО пришлись на имперский период 1897-1917 г2., когда Туркестанским отделом были реализованы обширные проекты в сфере среднего и высшего образования; автор приходит к выводу, что деятельность Туркестанского отдела РГО имела важное значение в реализации образовательных и культурно-просветительских проектов российского правительства в Туркестанском крае, что в итоге способствовало формированию образованного класса, развитию среднего и появлению высшего образования, и в иелом благотворно повлияло на формирование общественной жизни Центрально-Азиатского региона.

Ключевые слова: Российская империя; Туркестанский край; образование; просвещение; Русское географическое общество.

\footnotetext{
Закирова Маргарита Хайдаровна - младший научный сотрудник

Института всеобщей истории РАН, Россия, Москва.

E-mail: ritazak92@gmail.com
} 


\section{Zakirova M.H. The image of imperial Russia in the educational policy of the Turkestan Region at the turn of the XIX-XX centuries (On the example of the Turkestan Department of the Russian Geographical Society)}

Abstract. The article analyses the history of the development of educational programmes of secondary and higher education in Russian Turkestan in the late 19th - early 20 th centuries in the context of the imperial policy of Russia. The methodological basis of the article is Edward W. Said's concept of Orientalism, which allowed the author to define the policy of the Russian Empire in the field of education in Turkestan in the context of the «knowledge-power» («scientia-potential») structure, which fully reflected the interests of the Russian government in the organisation of research and education, which significantly influenced the formation of political and economic stability, contributing to the emergence of an educated stratum among the population. The study analyses the projects of the development of the schools proposed by N. Ilminsky, the ideas of K. von Kaufman and N. Ostroumov, and also examines the activities of the Turkestan Department of the Russian Geographical Society (RGS, 1896). The most important research of the scholars of the Turkestan Department of the RGS occurred during the imperial period, from 1897 to 1917. Separately, the Turkestan Department has implemented extensive projects in the field of secondary and higher education. The author concludes that the activities of the Turkestan Department of the RGS were crucial for the implementation of educational and cultural projects of the imperial government in the Russian Turkestan, which ultimately contributed to the formation of an educated class, the development of secondary and higher education, and generally had a beneficial effect on the formation of public life in the Central Asian region.

Keywords: Russian Empire; education; enlightenment; Russian Geographical Society; Turkestan Department.

Zakirova Margarita Haydarovna - Junior Research Fellow,

Institute of World History, Russian Academy

of Sciences, Russia, Moscow.

E-mail: ritazak92@gmail.com

Центрально-Азиатский регион ${ }^{1}$ представляет собой территорию, которой в различные исторические периоды владели правители тюркского каганата, монголы и представители центральноазиатских династий. В Центральную

1. В советской историографии к региону Центральной Азии было принято относить геополитикоэкономическую совокупность Кыргызстана, Таджикистана, Туркменистана и Узбекистана. Казахстан в силу больших территориальных размеров часто рассматривался как отдельный регион [Исмаилов, Папава 2010, с. 5]. В свою очередь Г.А. Хидоятов определял границы Центральной Азии в пределах Бухарского, Хивинского и Кокандского ханств, западно-китайской провиниии Синьизян, Афганистана и северо-восточной провинции Ирана - Хорасан [Хидоятов 1990, с. 8]. Привычное нам использование термина Центральная Азия было принято только после распада 
Азию по трассам Великого шёлкового пути поступали различные религиозные и философские, научные и культурные ценности [Кобзева, Закирова 2017]. Однако роль и значение Центральной Азии в геополитической истории менялись в ходе междоусобных войн центральноазиатских правителей, вплоть до вхождения региона в состав Российской империи. Сам процесс российской колонизации в Центральной Азии в конце XIX - начале XX в. происходил в условиях культурной гегемонии и военного доминирования. И колонизация представляла собой не буквально - захват, а умеренное присоединение территорий, представляющих внутреннюю часть России, т.е. своеобразную «внутреннюю колонизацию» [Эткинд 2018].

Если взглянуть на проблему освоения Российской империей территории центральноазиатских государств глазами путешественника, военного или ученого того периода, то Туркестанский край в полной мере был весьма привлекателен для российской и европейской общественности своей своеобразной культурной центральноазиатской «экзотикой». Не случайно Туркестан романтически называли «российской жемчужиной в пустынной оправе» [Яворский 1893, с. 1-2]. А. Эткинд отмечал, что именно «высокая литература и культура играли необычайную роль в Российском политическом процессе» [Эткинд 2018, с. 11]. Впоследствии именно ученые, публицисты и художники, желающие ознакомиться с природой, культурой и социальноэкономической жизнью народов, населяющих Центральную Азию, сыграли важную роль в интеграции этого региона в состав Российской империи. Что, собственно, и повлияло на последовательную политику российского правительства в Туркестане, выраженную аксиомой «знание - сила».

В этом отношении весьма актуальны подходы Э.В. Саида [Саид 2016]. В частности, что касается колониальной политики, Э.В. Саид делает акцент на необходимости получения Западом знаний о Востоке, как важном инструменте, ставящем восточный мир в зависимое положение от Запада [Саид 2016, с. 544]. Следовательно, колонизацию Центральной Азии Российской империей, можно рассматривать с точки зрения ориентализма. Так, научные общества выполняли важную функцию в сборе и обработке информации,

Советского Союза. Так, в январе 1993 г. - лидеры Казахстана, Узбекистана, Туркменистана, Киргизии и Таджикистана на встрече в городе Ташкент (Узбекистан) приняли решение о том, что общая территория будет носить официальное название - Центральная Азия [Восток и Россия 1998, с. 344]. Однако наряду с термином «Центральная Азия» научным сообществом также признан термин «Большая Центральная Азия». Если Центральная Азия составляет регион иентральноазиатских государств из перечисленных выше постсоветских стран, то Большая Центральная Азия представляет совокупность Центральной, Юго-Западной и Южной Азии, т.е. включает в себя, помимо территории Центральной Азии и северо-западную часть Китая и Афганистан [Исмаилов, Папава 2010, с. 63]. 
сведений и знаний о завоеванном регионе, что становилось прочной основой для выстраивания колониальной политики в крае.

Однако необходимо разделять понятия «западный и русский» ориентализм, так как колонизационная политика России в Центральной Азии значительно отличалась от, например, колонизации Великобританией Индии. Как отмечает М. Бассин, «по контрасту с европейской территориальной экспансией, которая всегда ассоциировалась с насилием и жестокостью, русская колонизация была органичным и естественным процессом, в ходе которого завоевание не играло вообще никакой роли» [Бассин 2005, с. 291]. Д.С. ван дер Ойе считает, что «русские смотрели на [Центральную] Азию через несколько разных оптических приборов», останавливаясь на двух, по его мнению, важных пунктах. Следует отметить, что из них «первое - ориентализм, как востоковедение и второе - культура» [Ван дер Ойе 2019, с. 19]. Исходя из этого российскому правительству для управления краем было важно не сохранение военного режима в регионе, а проведение преобразований в общественной жизни посредством активизации научной мысли, распространение русской культуры и образования.

Иную концепцию понимания роли Центральной Азии в политике Российской империи можно охарактеризовать как возможность самоидентификации европейцев через призму сравнения и анализа с чуждой Западу культурой [Тольц 2013; Миллер 2016]. Изучение истории Российского государства свидетельствует о том, что в России существовала тонкая грань между Востоком и Западом. Вбирая в себя эманации обеих культур - Россия составляла конгломерат народов, традиций и языков.

С формированием правительственной концепции продвижения России в Центральную Азию в середине XIX - начале XX в. актуальным становится вопрос о развитии экономического потенциала и культурного освоения региона. К 1897 г. Россия достигла границ выйти за которые уже не могла. Хивинское ханство располагалось к югу от Аральского моря и граничило с туркменскими племенами, кочевавшими между Каспийским морем и Амударьей до Ирана и Афганистана. Бухарский эмират, занимал территорию между Сырдарьей и Амударьей. Коканд находился между Сырдарьей и китайским Синьцзяном, а также занимал территории Ферганской долины и Ташкентского оазиса [Каррер д’Анкосс 2010, с. 83]. Все это пространство нуждалось в организации и создании благоприятной политической, экономической и научной среды для развития колониальной политики.

Одним из ключевых направлений политики России в ЦентральноАзиатском регионе являлось образование и просвещение молодежи в духе имперской идеологии. Отмечая влияние Константина Петровича Кауфмана на развитие образования в Туркестанском крае, следует отметить его попытки привлечь интерес научных обществ и российской общественности к идее 
развития школьного образования в Туркестане. Для обеспечения централизации и постоянного контроля над учебными заведениями Кауфман учредил при штабе генерал-губернатора края должность главного инспектора Туркестанских училищ [Положение об управлении Туркестанским краем 1886, с. 2-4].

Важную роль в развитии системы общего образования в Туркестане сыграл Николай Петрович Остроумов, бывший ученик Николая Ивановича Ильминского - казанского профессора и реформатора школьного образования для новокрещеных татар. Следует отметить, что К.П. Кауфман при постановке вопроса об образовании средних школ планировал работать с Н.И. Ильминским, однако курс общего образования, предпочтительный для К.П. Кауфмана, не отвечал религиозному духу и идеям Н.И. Ильминского. В 1877 г. Н.П. Остроумов в должности учителя мужской гимназии вместе с семьей был командирован на постоянное место жительства в Ташкент. Более подробно свое пребывание в Туркестане Н.П. Остроумов осветил в работе «К.П. фон Кауфман. Личные воспоминания и исторический очерк народного образования в крае» [Остроумов 1899]. Н.П. Остроумов будучи преемником идей Н.И. Ильминского, придерживался линии невмешательства в местные религиозные вопросы и поддерживал общее и доступное образование для всех без активной миссионерской деятельности.

В 1869 г. К.П. Кауфман, желая ознакомиться с программой обучения новокрещеных татар по системе Н.И. Ильминского, отправил в Казань Александра Людвиговича Куна - чиновника особых поручений при Туркестанской канцелярии, в дальнейшем занимавшего должность главного инспектора училищ Туркестанского края. Н.И. Ильминский познакомил А.Л. Куна со своей системой обучения и показал ему школу для новокрещеных татар. В представленной через А.Л. Куна записке он предлагал К.П. Кауфману широкий план развития как школьного образования, так и распространения христианства в Центральной Азии.

При личной встрече К.П. Кауфмана с Н.И. Ильминским выяснилось, что стремления их различны. Н.И. Ильминский хотел вести преобразования в школе по своей системе, а К.П. Кауфману был нужен человек который бы решил вопрос с образованием в Туркестане в целом [Бендриков 1960, с. 62]. В частности, К.П. Кауфман планировал создать в Ташкенте такие учебные заведения, которые бы соответствовали высшим научным школам и наравне с другими могли бы реализовывать научные проекты, отвечающие экономическим потребностям российского правительства в Туркестанском крае. В 1873 г. К.П. Кауфман представил Государственному совету «План устройства учебной части и народного образования в Туркестанском крае». Согласно предложенной программе, учебные заведения должны были служить не просвещению в целом, а быть направлены на приобретение определенных знаний, навыков и умений. Так, в Ташкенте впервые под руководством 
ученого-энтомолога В.Ф. Ошанина была открыта «Туркестанская школа шёлководства». В 1885 г. при школе были организованы первая дренажная станция и опытное поле [Бендриков 1960, с. 143-144]. Впоследствии здесь были выведены две итальянские породы шелкопряда. С основанием Сельскохозяйственного общества (1885) и Туркестанского отдела РГО (1897) на станциях школы проводились систематические исследования в области ботаники, зоологии и сельского хозяйства. Однако школы, специализирующиеся по научнопроизводственной части, широко распространены не были.

В основном туркестанская администрация сосредоточилась на организации четырехклассных уездных училищ. В программу училищ входило обучение различным ремеслам: работе по дереву, сапожному делу, ковроткачеству и сельскохозяйственному делу. Соответственно были созданы начальные училища, в которых основное обучение проводилось сезонно и зависело от цикличности сельскохозяйственных работ и перегона скота. Следовательно, идеи Н.И. Ильминского, основанные на связи общего образования с православием, не отвечали запросам российского правительства в Туркестане. Основной целью создания подобных учебных учреждений являлась необходимость в подготовке кадров для сельского хозяйства, горного дела и в целом специалистов в различных областях. Подобная программа позволила бы создать среди местного населения определенную прослойку, владеющую русским языком, грамотой и обладающую определенными профессиональными навыками, необходимыми для формирования административных и экономических связей в Центрально-Азиатском регионе.

Свое отношение к образованию в Туркестанском крае Н.И. Ильминский излагал в письме к Петру Дмитриевичу Шестакову - Попечителю казанского учебного округа. Н.И. Ильминский сожалел, что их интересы с К.П. Кауфманом разошлись, так как программу образования в Туркестане он видел иначе. «Скажу откровенно, - писал Ильминский, - она (программа. - М. 3.) списана с натуры, с Казанской школы для детей крещеных татар» [см.: Переписка Остроумова и Ильминского, л. 8].

В «Программе школы для крещеных инородцев Восточной России» Н.И. Ильминского (1898), отмечается, что инородцы Восточной России в основном исповедуют мусульманскую религию, не владеют русским языком. «Подобное обстоятельство ставило инородцев в исключительные условия и налагало на воспитывающий и учащий персонал инородческих училищ особые требования» [Программа школы, л. 1].

Основная идея школы заключалась в создании четырехклассных училищ с двумя отделениями. В младшем отделении преподавание должно было вестись на языке коренного населения, а в старшем - на русском. Основными предметами являлись: Закон Божий, русский язык, славянское чтение, инородческое чтение, счет, письмо, пение и гимнастика. Занятия рассчитаны были на 32 часа 
в неделю в младшем отделении, и на 33 часа в старшем [Программа школы 1898, л. 5-6]. Закон Божий являлся самым обширным курсом. Славянское чтение также было ориентировано на чтение духовных текстов и даже пение имело целью заучивание псалмов. Можно сразу отметить, что такая система образования была неприемлема для населения Туркестана, так как образование в крае носило религиозный характер. Туркестанским руководством не планировалось осуществление миссионерской деятельности в регионе, которую Н.И. Ильминский предполагал вести вместе с образованием.

Свою позицию по данному вопросу Н.И. Ильминский выразил в письме к туркестанскому генерал-губернатору: «Вам собственно нужен человек, который бы заведовал учебной частью в Туркестанской области, а я прежде полагал, что Вам нужны те начало и идеи, которые должны лечь в основании учебной части» [Переписка Остроумова и Ильминского, л. 6]. В целом, программа Н.И. Ильминского была несвоевременной, так как в крае необходимо было решать не только вопросы, связанные с изучением русского языка и приобщением местного населения к российской культуре. Перед туркестанской администрацией прежде всего стояла задача проведения образовательных реформ. Кроме того существовала проблема с набором учеников из местного населения, так как долгое время родители отдавали предпочтение религиозным школам, по окончании которых их дети, должны были стать муллами [Котюкова 2014].

Признавая проблемы, возникающие в сфере образования перед русской администрацией в Туркестане, Н.И. Ильминский отмечал, что «русское образование необходимо местному населению для сотрудничества и работы, а мусульманские школы в этом отношении следует игнорировать» [Письма Ильминского к Остроумову, л. 5]. Более того, он предлагал придерживаться нейтралитета по отношению к мактабам² «потому что, принявши на свое попечение эти школы, надо будет заботиться об их интересах... Мне представляется невозможным достигнуть через слияние магометанских начал или принципов и догматов с европейской наукой и цивилизацией, не то чтобы обрусение, а даже какое-либо расположение к русским людям к русскому государству. Через это слияние может даже цивилизацию-то обратить в орудие против русского народа и государства, как это и видим теперь в Турции» ${ }^{3}$ [Письма Ильминского к Остроумову, л. 5]. Н.И. Ильминский предлагал оставить мусульманские школы как религиозные учебные заведения, и открыть

2. Мактаб - мусульманская начальная школа в странах Востока и Российской империи. Как правило - светского направления.

3. Имеется в виду движение младотурок - политическое движение в Османской империи, которое, начиная с 1876 г., пыталось провести либеральные реформы в сфере образования и политики, создать конституционное государственное устройство. 
русские школы для местного населения с целью получения общего образования, так как «жители торгаши, торгуют с русскими, им поэтому нужно знать русскую грамоту и русское счетоводство, и форму векселей и т.п.» [Письма Ильминского к Остроумову, л. 56].

Еще больше Н.И. Ильминского беспокоило усиление влияния татарской интеллигенции, которая предлагала изучение «европейской науки» на восточных языках - татарском или турецком. В письме Н.П. Остроумову Н.И. Ильминский предупреждает о введении мусульманами европейского образования на татарском языке, видя в этом угрозу развитию русской культуры. Н.И. Ильминский так описывает это явление: «теперь в каждой губернии началась оппозиция татар - перечат против правительства об изучении русского языка муллами» [Письма Ильминского к Остроумову, л. 78].

Опасения по поводу развития влияния татарского языка объясняется следующим образом: в Оренбурге в русско-киргизском управлении на должностях переводчиков и писцов использовались татары, официальным языком общения русской и киргизской администрации был признан татарский язык. Крупные купцы и влиятельные люди киргизского происхождения разговаривали на татарском. В 1850 г. в Оренбурге открылась школа для киргизских детей где преподавание велось на татарском языке. Это могло представлять определенную угрозу русской колониальной политике в Туркестанском крае [Зпоменский 1900, с. 8]. Н.И. Ильминский подчеркивал, что «появляется много разных татарских произведений, так что гляди в оба, что нередко ядовитые-то намеки, укрытые между строками, их надо раскрывать... Было прекращено печатание Акмолинскими областными ведомостями Истории Вамбери, не появится в "Переводчике" обещанная энциклопедия» [Письма Ильминского к Остроумову, л. 79]. Большая опасность заключалась не в том, что «История Вамбери» и другие произведения будут переведены на татарский язык, а в том, что в среде нарождающейся мусульманской интеллигенции начнется движение за развитие науки в мусульманской среде. Впоследствии они смогут выступить и за объединение тюркских народов против российской политики, что грозит крахом не только системы инородческого образования, но и внутренней колонизации на Востоке России.

При этом роль русского народа в Туркестане Н.И. Ильминский видел «в образовании киргизов и других инородцев Туркестанского края... Чтобы не испугала русская идея, необходимо показать, что она к ним вполне применима и не только не разрушает их благосостояние, но даст им выгоды образования и умственно-нравственного развития, этой прочной основы всякого благосостояния» [Письма Ильминского к Остроумову, л. 89]. Следует учесть, что сам Н.И. Ильминский оставался преданным идее крещения татар в Восточной России, что было запрещено еще со времен Екатерины II, но впоследствии приняло новый размах. Кроме того, он непрерывно вел переписку со 
священниками, учеными богословами и неоднократно обсуждал данный вопрос с Н.П. Остроумовым, своим преданным учеником.

Ю.С. Флыгин в работе «Николай Остроумов: востоковед, просветитель, летописец, эпохи» раскрывает все стороны трудовой и общественной деятельности Н.П. Остроумова, посвятившего свою жизнь изучению истории, языкам и культуре народов населяющих Туркестанский край. Будучи знаком с положением образования в крае, он сумел оказать значительное влияние на развитие средней школы в крае [Флыгин 2016]. Более того, Н.П. Остроумов, занимаясь вопросами развития образовательных программ, придавал большое значение условиям, в которых должны были проходить учебные занятия.

Н.П. Остроумов, определяя политические задачи Российской империи в Туркестане, видел их «в слиянии иноплеменных жителей Туркестанского края с коренным русским населением, от которого первое отличается не только происхождением и языком, но и религией и многими сторонами домашнего и общественного быта» [Остроумов, л. 8]. Под «слиянием» следует понимать стирание культурных границ, в частности исследование материальной и духовной культуры Центральной Азии, просвещение местного населения, согласно идеологии Российской империи. В целом Н.П. Остроумов сформулировал основные задачи российской администрации в Туркестане, которые должны были привести к развитию «административных, экономических и политических принципов и выработать такие отношения к туземному населению, которые бы не особенно стесняли его и в то же время были бы согласны с основными государственными интересами России» [Остроумов, л. 9].

В отношении просвещения Н.П. Остроумов выделял необходимость «устранить все, что может способствовать поддержанию и укреплению среди туземцев мусульманской образованности (печатание мусульманских книг, брошюр, гравюр и пр.)» [Остроумов, л. 16]. При этом он подчеркивал, что необходимо вести активную пропагандистскую деятельность за распространение российского светского (не церковного) образования в Туркестанском крае. Основной упор Н.П. Остроумов делает на науку и образование, просвещение и русификацию местного населения. Н.П. Остроумов отмечал, что необходимо ввести «образование туземного юношества в правительственных школах; обязательное распространение русского языка среди туземного населения; назначение светской власти всех духовных должностных лиц, кроме имамов, которые должны быть избраны обществом мусульман; просветить постепенно инородцев и сближать их с русским духом и с Россией» [Остроумов, л. 17]. Таким образом, Н.П. Остроумов в своих рассуждениях о приоритетах Российской политики в Центральной Азии пришел к выводу о имеющихся преимуществах колонизации Центральной Азии при условиях принятия 
Российским правительством во внимание внутреннего положения в регионе. Речь шла об освоении Туркестанского края не при помощи силовых структур, а путем культурного вовлечения его народов в жизнь Российского государства.

Возвращаясь к центральному вопросу - проблемы развития образования в Туркестанском крае, следует выделить исключительную роль российских ученых в сотрудничестве с Ташкентской учительской семинарией и научными обществами, в частности с Туркестанским отделом РГО. Так, многие программы в сфере образования разрабатывались на базе Ташкентской учительской семинарии основанной в 1879 г. С 1890 г. советом Ташкентской семинарии были основаны метеорологические станции для семинаристов под руководством В.Ф. Ошанина. Станции были оборудованы Туркестанским военно-топографическим отделом на семинарском земельном участке с целью подготовки будущих метеорологов-наблюдателей. Кроме того, была разработана программа по огородничеству и садоводству, предусматривающая, что каждому ее воспитаннику при поступлении отводится определенное количество земли, на котором он производит опытные посевы и посадки [Бендриков 1960, с. 153-154]. Семинаристы также осваивали технику прививки растений, учились определять и бороться с сельскохозяйственными вредителями. В целом программа обучения в дальнейшем совпадала с исследованиями, проводившимися членами Туркестанского отдела РГО.

С 1900 г. отдельные образовательные и культурные программы в форме учебных экспедиций реализовывались Туркестанским кружком любителей археологии (ТКЛА). При участии педагогов и учителей Туркестана в 1903 г. был основан Ташкентский педагогический кружок, а с 1910 г. в Ташкенте ежегодно начал заседать Съезд педагогов Туркестанского края.

Определяя историческую роль Туркестанского отдела в развитии научной мысли в Центрально-Азиатском регионе, следует отметить его исключительное влияние на развитие просвещения и культуры в Туркестанском крае наравне с другими научными и общественными учреждениями. Правление Туркестанского отдела занималось разработкой методической и учебной литературы по географии и истории Туркестанского края, организовывало открытые общие собрания Туркестанского отдела для учеников гимназий.

На заседаниях правления и общих собраниях Туркестанского отдела активное участие принимали педагоги и руководители, общественные деятели и меценаты, реализующие свою деятельность в сфере образования. Многие члены Туркестанского отдела занимали должности инспекторов, директоров и преподавателей Ташкентской мужской и женской и областных гимназий, училищ и Ташкентской учительской семинарии. Они были достаточно хорошо знакомы с положением существующего образования в ЦентральноАзиатском регионе. Выдающийся вклад в науку сделал преподаватель кадетского корпуса, действительный член Туркестанского отдела Н.А. Зарудный. 
В 1907-1914 гг. он собрал ценные орнитологические коллекции. Обязанностям секретарей Туркестанского отдела отдавали много времени преподаватели средней школы: с конца 1899 г. - Н.Г. Маллицкий, с 1902 А.П. Ростовский, с 1908 - В.Д. Городецкий, с 1912 г. - А.В. Панков. В Известиях ТО ИРГО в 1912-1918 гг. печаталась «Хроника научной жизни Туркестана», которую вели преподаватели ташкентских гимназий Е.К. Бетгер и А.В. Пекков. Кроме того, за период с октября 1912 по ноябрь 1916 г. там же издавалась библиография книг и статей по туркестановедению, составленная преподавателем А.В. Лаповым [Бендриков 1960, с. 359].

Краеведческие описания в Известиях ТО ИРГО оставили инспектора народных училищ П.Е. Кузнецов и В.Д. Городецкий [Бендриков 1960, с. 361]. Заместителем председателя Туркестанского отдела и фактическим руководителем в последние годы перед октябрьской революцией был Н.Г. Маллицкий. Отдельно в этом отношении следует выделить деятельность Н.П. Остроумова директора Ташкентской учительской семинарии в 1879-1882 гг., а с 1883 г. занимавшего должность директора Ташкентской мужской гимназии, и принимавшего непосредственное участие в развитии системы образования в Туркестанском крае.

Масштабные работы по реализации образовательно-просветительских проектов правление Туркестанского отдела начало проводить в начале XX в. В 1906 г. впервые о проблеме образования высказался Н.Г. Маллицкий на заседании общего собрания Туркестанского отдела. В своем выступлении по теме «О горной стране в верховьях Зеравшана» Н.Г. Маллицкий отмечал, что для поднятия уровня жизни населения необходимо улучшить культурную и просветительскую сферы общественной жизни в крае [Известия ТО ИРГО 1907, с. 182-186]. По мнению докладчика, в Зеравшанской долине, как и во всем Туркестанском крае следует улучшить условия русских школ и медицинских пунктов для местного населения, проводить культурные мероприятия которые будут способствовать его просвещению. Для осуществления этих задач правление Туркестанского отдела постановило активизировать консультативную работу членов отдела с учебными учреждениями и научными центрами.

Реализация поставленной цели активировалась с участием членов Туркестанского отдела в работе проводимых ежегодно съездов преподавателей в городе Ташкент. В конце декабря 1910 - начале января 1911 г. в Ташкенте состоялся первый Съезд преподавателей средних школ Туркестанского края. Преподаватели ходатайствовали о созыве съезда для обсуждения вопросов методического и воспитательного характера. В съезде приняли участие 149 человек (из них 30\% женщин), не считая председателя и секретаря из таких городов, как: Ташкент, Самарканд, Скобелев, Чарджуй, Ашхабад, Верный и Чимкент [Бендриков 1960, с. 301]. 
Заседание съезда преподавателей Туркестанского края вынесло на рассмотрение преподавателей и научных обществ Туркестана вопрос об отсутствии специальной учебной литературы по Туркестанскому краю, удовлетворяющей требованиям педагогического состава. Преподаватели местных учебных заведений, распределяя учебный материал, сами определяли объем и нагрузки, включая общеобразовательные знания по Туркестану [Думенко 1957, с. 12]. Так, в изучение русской грамматики они вводили некоторые сведения по истории, географии и естествознанию Туркестанского края, которые шли не отдельным предметом, а усваивались на уроках русского языка. Преподаватели боролись за увеличение часов по отдельным предметам, имеющим важное значение в освоении географических и краеведческих знаний по Центрально-Азиатскому региону.

Представления о своеобразных природных и бытовых условиях Центрально-Азиатского региона безусловно отражались на уровне образования в Туркестанском крае. Российские программы не соответствовали местным условиям и образу жизни, данные обстоятельства заставляли видоизменять учебные программы применительно к местным условиям и к составу учащихся. Собственно основная задача Съезда преподавателей заключалась в необходимости организовать в школах Туркестана изучение географии и истории Туркестанского края. В докладе натуралиста А.П. Ростовского «О трудностях преподавания естествознания в Туркестанском крае» говорилось: «Все учебники, которыми мы должны пользоваться, составлены применительно к европейской флоре, фауне и вообще к природе Европейской России. Таким образом, при своеобразии окружающих нас природных и физикогеографических условий учебники эти весьма мало подходят». А.П. Ростовский предложил поручить известному знатоку флоры Туркестанского края действительному члену Туркестанского отдела Б.А. Федченко составить определитель растений необходимый для изучения в школе.

Эти проблемы были представлены и в докладе преподавателя географии М.В. Лаврова на объединенном заседании секции географии, истории, естествознания и рисования. Тема заседания была сформулирована так - «Необходимо ли давать учащимся в средних и низших учебных заведениях Туркестанского края знания по истории и географии края?». М.В. Лавров внес предложение составить коллективными силами преподавателей книгу для чтения по истории, географии и экономической жизни Туркестана с приложением к ней в виде учебных карт. По согласованию с участниками Съезда преподавателей было принято решение составить сборник (альманах) по истории, географии и естествознанию Туркестана [Бендриков 1960, с. 301]. В задачу Туркестанского отдела входило объединить всех ученых и преподавателей, связанных с преподаванием учебных предметов на местном материале, для подготовки специальной учебной литературы и программ. Туркестанский 
отдел, являясь постоянным научным учреждением в сфере изучения географии Центрально-Азиатского региона, обязался вести консультативные работы с Педагогическим кружком по вопросам учебной литературы [Известия ТО ИРГО 1912, с. 18-19]. Кроме того, еще с 1908 г. правление Туркестанского отдела рассылало периодические издания, печать общества в средние учебные заведения по одному экземпляру каждого издания, всего в количестве 16 экземпляров [Известия ТО ИРГО 1911, с. 98-99]. Таким образом, Туркестанским отделом было положено начало в деле издания методических пособий для учебных заведений Туркестанского края.

Впоследствии членами Туркестанского отдела многократно составлялись библиографические научные списки, систематические каталоги по научной и учебной литературе. Отдельно следует выделить издание «Определитель растений Ташкента и его окрестностей». Позже Туркестанским отделом была издана целая серия определителей по отдельным ботанико-географическим отраслям науки для средних школ. Кроме того, был выпущен в двух редакциях «Путеводитель по лечебным местностям Туркестана». В первом выпуске были систематизированы все имеющиеся данные по заповедникам Туркестана. Во втором сборнике, подготовленном в 1916-1917 гг., собраны материалы путем анкетирования и специальных поездок с фотофиксацией [Отчет о деятельности 1927, с. 21]. С 1912 г. Туркестанский отдел начал выпускать «Библиографические указатели книг и статей по Туркестановедению» [Библиографические указатели 1915, 1916]. Географом М.В. Лавровым под при поддержке Туркестанского отдела был составлен учебник по истории и географии Туркестана, выдержавший два издания - 1914 и 1916 гг. [Лавров 1916].

Деятельность Туркестанского отдела не ограничилась только работой с учебными учреждениями и подготовкой специальной методической литературы. Так, в 1914 г. член Туркестанского отдела П.Е. Кузнецов подготовил доклад, посвященный туземному образованию в Алжире [Известия ТО ИРГО 1916, с. 267-270]. В своем выступлении П.Е. Кузнецов подчеркивал необходимость введения в Туркестане европейской системы образования на примере организации французско-туземных школ в Алжире, в сравнении с которыми школы Туркестанского края значительно проигрывали. Задачей правления Туркестанского отдела докладчик полагал в определение наиболее перспективных направлений в сфере образования для привлечения учащихся и их родителей. Однако, по мнению совета Туркестанского отдела, основой образования в Туркестане должно было стать научное знание, поэтому перспективы в развитии образования видели в организации высшего образования в Туркестанском крае, как научной базе для проведения обширных исследовательских работ.

Впервые основательная работа в сфере высшего образования в Туркестане была проведена членом Туркестанского отдела инженером К.Г. Давыдовым. 64 
В докладе на общем собрании Туркестанского отдела 27 сентября 1916 г. «О высших учебных заведениях в Ташкенте (Туркестанский политехникум)» Давыдов поставил проблему реализации в Туркестанском крае высшего образования на базе научной школы [Давыдов 1917, с. 5-9; Бендриков 1960, с. 356]. Докладчик делал упор на перспективе создания высшего технического учебного заведения в Туркестане, на основе которого могли бы быть реализованы как учебные, так и научные задачи. В целом, учитывая особенности края, организовать в Ташкенте Политехникум вместо классического университета или института было более практичным и перспективным, так как на научной базе подобного учебного заведения можно было не только готовить инженеров и техников, специалистов в области гидрологии и обработки хлопка, но и проводить различные научные исследования, т.е. создать некий научный центр. Г.К. Давыдов подчеркивал, что учебное заведение по типу Политехникума должно включать в себя следующие отделения: агрономическое, инженерное (с двумя направлениями - гидротехническим и по обработке хлопка), восточное, медицинское и юридическое [Давыдов 1917, с. 9].

Однако вопрос о создании подобного учреждения долго оставался открытым. В организации высшего учебного заведения в Ташкенте вместе с Туркестанским отделом принимали участие Туркестанский кружок любителей археологии и Общество естествоиспытателей и врачей (1908 г.) [Бендриков 1960, с. 358]. Туркестанский отдел с конца 1916 г. входил в состав комиссии по созданию Туркестанского народного университета. В итоге только в 1918 г. был создан Туркестанский народный университет, организованный на базе технического, медицинского, юридического и восточного направлений. Более того, члены Туркестанского отдела в первый год существования университета организовали чтение циклов лекций по истории, этнографии и географии [Отчет о деятельности Среднеазиатского отдела 1927, с. 22].

Правление Туркестанского отдела большое внимание уделяло просвещению населения и организации научно-популярных лекций. В 1908 г. на заседании правления Туркестанского отдела было принято решение приглашать преподавателей и учащихся старших классов средних учебных заведений на заседания Туркестанского географического общества - числом не более 20 человек [Известия ТО ИРГО 1911, с. 99].

Ярким примером участия Туркестанского отдела в организации просветительских мероприятий является проведение популярных лекций в помощь жертвам войны 1914 г. В этом отношении Туркестанский отдел, во-первых, выступал как проводник патриотических идей, способствовал укреплению духа населения Туркестана в трудный военный период. Во-вторых, подобные мероприятия, повышали уровень сознания населения, расширяли рамки общения, выполняли задачи объединения и просвещения населения. Так, в 
начале 1914 г., по предложению правителя дел А.В. Панкова, правление Туркестанского отдела обратилось к членам Туркестанского отдела и другим научным учреждениям Туркестана с приглашением принять участие в чтении популярных лекций по географии, этнографии и истории стран, сопредельных с Российской империей и других государств, а также по отдельным естественно-научным вопросам. Плата за лекции была предложена минимальная (не выше 30 коп.); весь сбор от лекций предназначался для помощи семьям убитых воинов действующей армии [Известия ТО ИРГО 1916 , с. 283-285].

В январе и феврале 1915 г. туркестанский отдел устроил серию научных лекций, лекторами выступили Л.М. Воротаев по теме «Бельгия», С.С. Богословский - «Очерк развития исторического прогресса в XIX в.», Е.П. Виноградов - «Праславянская культура» [Известия ТО ИРГО 1916, с. 293301]. Успех лекций был очевидным, среднее число слушателей составило свыше 130 человек; лекции проводились в зале Ташкентской Городской Думы.

Следует отметить, что правление Туркестанского отдела самым серьезным образом отнеслось к данному мероприятию. Члены правления тщательно отбирали темы докладов, предложенных к обсуждению общим собранием. Так, правлением Туркестанского отдела был утвержден список тем лекций, соответствующих тематике и направлению РГО на 1915 г. [Известия ТО ИРГО 1916, с. 287-288]. Интересные темы были предложены М.В. Лавровым-Галичиным и С.М. Абрамовым - «Очерки истории Сибири» и В.И. Миловенковым - «Фотография и ее значение». В правление Туркестанского отдела были поданы заявки Г. Ростовского с темой «Человек, государство и национальность», П.А. Комарова и А.В. Трапезникова с темой «О глупости (психологический очерк)». Отдельно подготовленная лекция «Коран и вино» Г. Ростовского и П.А. Комарова правлением Туркестанским отдела была исключена как признанная несоответствующей по содержанию задачам РГО [Известия ТО ИРГО 1916, с. 289-300]. Таким образом, деятельность Туркестанского отдела в организации научно-образовательных лекций выражалась в популяризации и продвижении знаний по географии и истории.

Таким образом, образование стало прочной основой в введении русской грамоты и культуры в Туркестанском крае, оно повлияло на развитие научной школы, социально-экономическую и культурную жизнь народов Туркестанского края. Проекты и планы по организации школьного образования в Туркестане были отражены в идеях К.П. Кауфмана, Н.И. Ильминского, Н.П. Остроумова и других туркестанских реформаторов. Их деятельность в развитии регионального образования была направлена на создание общих школ, в которых учащиеся могли бы обрести как практические навыки, так и общие знания о регионе. 
Следует отметить важную роль Туркестанского отдела в создании научной литературы, а также учебников по географии и краеведению для средних школ. Еще более важную задачу Туркестанский отдел выполнял, поддерживая постоянную связь с Педагогическим кружком и Съездом педагогов Туркестанского края, осуществляя консультативную и координирующую функции. Реализация проекта по организации высшего учебного заведения в Туркестане стала апогеем деятельности Туркестанского отдела.

Реализация образовательных программ в Туркестане способствовала, с одной стороны, созданию диалога между учеными, общественными деятелями и педагогами Туркестанского края по вопросам развития культурной, научной и образовательной сфер, с другой - создало почву для развития среднего и высшего образования, для появления научных школ и профессиональной прослойки среди населения.

\section{Библиография}

Бассин М. Россия между Европой и Азией: идеологическое конструирование географического пространства // Российская империя в зарубежной историографии. Работы последних лет: Антология / Сост. П. Верт, П.С. Кабытов, А.И. Миллер. М.: Новое издательство, 2005. 696 с.

Бендриков К.Е. Очерки по истории народного образования в Туркестане. М.: Академия Педагогических Наук СССР, 1960. 503 с.

Библиографические указатели книг и статей по Туркестановедению за 1912-1914 г. // Известия Туркестанского отдела Императорского русского географического общества (ТО ИРГО). 1915. Т. 10. Вып. 1. С. 257-276.

Библиографические указатели книг и статей по Туркестановедению за 1914-1915 г. // Известия ТО ИРГО. 1916. Т. 12. Вып. 2. С. 311-339.

Восток и Россия на рубеже XXI века. М., 1998. 367 с.

Давыдов Г.К. О высших учебных заведениях в Ташкенте (Туркестанский политехникум) // Известия ТО РГО. 1917. Т. 13. Вып. 1. С. 5-9.

Думенко М.Ф. Русско-туземные школы Туркестана. Ташкент: Мин-во просв. Уз ССР, 1957. 15 c.

Заседание правления ТО ИРГО, 15.10.1908. Протокол № $1 / /$ Известия ТО ИРГО. 1911. T. 8. C. $98-99$.

Заседание правления ТО ИРГО, 3.02.1912. Протокол № 7 // Известия ТО ИРГО. 1912. Т. 8. Вып. 3. С. 18-19.

Заседание правления ТО ИРГО, 11.11.1914. Протокол № 9 // Известия ТО ИРГО. 1916. Т. 12. Вып. 2. С. 283-285.

Зпоменский П.В. Н.И. Ильминский в Туркестанском крае. Казань: Типолитография Императорского Университета, 1900. 84 с.

Исмаилов Э., Папава В. Центральная Евразия: геополитическое переосмысление. Стокгольм: CA \& CC Press, 2010. 168 c.

Каррер д’Анкосс Э. Евразийская империя: история Российской империи с 1552 года до наших дней. Москва: РОССПЭН, 2010. 431 с.

Кобзева О.П., Закирова М.Х. Шелковый путь в потоке истории. Ташкент: Professional Solution, 2017. $283 \mathrm{c}$. 
Котюкова Т.В. «Мусульманская школа и как с ней бороться»: имперский опыт в Туркестане в начале XX в. // ЭНОЖ «История». 2014. № 4 (27). [Электронный ресурc] URL: https:// history.jes.su/s207987840000742-5-1 (дата обращения 15.01.2021).

Лавров М.В. Туркестанская география и история края. М., 1916. 208 с.

Миллер А.И. Нация, или Могущество мифа. СПб.: Издательство Евразийского университета в Санкт-Петербурге, 2016. 146 с.

Общее собрание ТО ИРГО, 17.11. 1906. Протокол № 2 // Известия ТО ИРГО. 1907. Т. 7. C. $182-186$.

Общее собрание ТО ИРГО, 4.03.1914. Протокол № 1 // Известия ТО ИРГО. 1916. Т. 12. Вып. 2. С. 267-270.

Общее собрание ТО ИРГО, 4.01.1915. Протокол № 11 // Известия ТО ИРГО. 1916. Т. 12. Вып. 2. С. 287-288.

Остроумов Н.П. Константин Петрович фон Кауфман, устроитель Туркестанского края. 1877-1881 гг. Ташкент, 1899. 286 с.

Остроумов Н.П. Общий взгляд на задачу русской администрации Туркестанского края к мусульманскому населению // Государственный архив Республики Татарстан (ГА РТ). Ф. 968. Оп. 1. Ед. хр. 43.23 л.

Отчет о деятельности Среднеазиатского отдела Государственного русского географического общества (РГО) за время с 1897 по 1927 г. // Отчеты за 1926-1927 гг. и за время с 1897 по 1927 г. Среднеазиатского отдела Государственного РГО. Ташкент, 1927. С. 18-25.

Отчет правления ТО ИРГО 1914 г. // Известия ТО ИРГО. 1916. Т. 12. Вып. 2. С. 293-301.

Переписка Н.П. Остроумова и Н.И. Ильминского по вопросам инородческого образования // ГА РТ. Ф. 968. Оп. 1. Ед. хр. 16. 56 л.

Письма Н.И. Ильминского к Н.П. Остроумову (6 октября $1877-8$ ноября 1890 гг.) // ГА РТ. Ф. 968. Оп. 1. Ед. хр. 78. 89 л.

Положение об управлении Туркестанским краем. СПб.: Гос. тип., 1886. 27 с.

Программа школы для крещеных инородцев Восточной России. Казань, 1898 // ГА РТ. Ф. 968. Оп. 1. Ед. хр. 189.9 л.

Саид Э.В. Ориентализм. Западные концепции Востока. СПб.: Русский мир, 2016. 619 с.

Схиммельпеннинк ван дер Ойе Д. Русский ориентализм: Азия в российском сознании от эпохи Петра Великого до Белой эмиграции. М.: Политическая энциклопедия, 2019. 288 с.

Тольц В. «Собственный Восток России»: Политика идентичности и востоковедение в позднеимперский и раннесоветский период. М.: Новое литературное обозрение, 2013. 336 с.

Флыгин Ю.С. Николай Остроумов: востоковед, просветитель, летописец эпохи. Ташкент: Turon zamin ziyo, 2016. $92 \mathrm{c}$.

Хидоятов Г.А. Моя родная история. Ташкент: Укитувчи, 1990. 303 с.

Эткинд А. Внутренняя колонизация. Имперский опыт России. М.: Новое литературное обозрение, 2018. 448 с.

Яворский И.Л. Средняя Азия. Культурные успехи и задачи в ней России. Публичная лекция, прочитанная 19 июля 1893 года в пользу попечительства о недостаточных студентах сего университета. Одесса: Типография Войск Одесского Военного Округа, 1893. 38 с.

\section{References}

Bassin M. Rossiya mejdu Evropy i Aziey: ideologicheskoe konstruirovanie geograficheskogo prostranstva. Rossiyskaya imperiya v zarubejnoy istoriografii. Raboty poslednih let: Antologiya / Sost. P. Vert, P.S. Kabytov, A.I. Miller [Bassin M. Russia between Europe and Asia: Ideological Construction of Geographical Space. Russian Empire in Foreign Historiography. Works of recent 
years: Anthology. Comp. P. Werth, P.S. Kabytov, A.I. Miller]. Moscow: Novoe izdatelstvo, 2005. 696 p. (In Russ.)

Bendrikov K.E. Ocherki po istorii narodnogo obrazovaniya v Turkestane [Bendrikov K.E. Essays on the history of public education in Turkestan]. Moscow: Akademiya Pedagogicheskih Nauk USSR, 1960. 530 p. (In Russ.)

Bibliograficheskie ukazateli knig i statey po Turkestanovedeniu za 1912-1914 gg. [Bibliographical Indexes of Books and Articles on Turkestan Studies for 1912-1914] // Izvestiya Turkestanskogo otdela Imperatorskogo Russkogo Geograficheskogo Obshchestva (TO IRGO). 1915. T. 10. Vol. 1. P. 257-276. (In Russ.)

Bibliograficheskie ukazateli knig i statey po Turkestanovedeniu za 1914-1915 gg. [Bibliographical Indexes of Books and Articles on Turkestan Studies for 1912-1914] //Izvestiya TO IRGO. 1916. T. 12. Vol. 2. P. 311-339. (In Russ.)

Vostok i Rossiya na rubezhe 21 veka [The East and Russia at the Turn of the $21^{\text {st }}$ Century] Moscow, 1998. P. 334. (In Russ.)

Davydov G.K. O vischix uchebnyh zavedtniyah v Tashkente (Turkestanskiy politexnicum) [Davydov G.K. About higher educational institutions in Tashkent (Turkestan Polytechnicum)] // Izvestiya TO IRGO. 1917. T. 13. Vol. 1. P. 5-9. (In Russ.)

Dumenko M.F. Russko-tuzemni chkoli Turkestana [Dumenko M.F. Russian-Turkestan schools]. Tashkent: Ministry of Public Health of the Uzbek SSR, 1957. 15 p. (In Russ.)

Zpomenskiy P.V. N.I. Ilyminskiy $v$ Turkestanskom krae [Zpomensky P.V. N.I. Ilminsky in Turkestan Territory]. Kazan: Tipolitografia Imperatorskogo Universiteta, 1900. 84 p. (In Russ.)

Zasedanie pravleniya TO IRGO, 15.10.1908. Protokol N 1[Meeting of the Board 15.10.1908. Minutes N 1] // Izvestiya TO IRGO. 1911. T. 8. P. 98-99. (In Russ.)

Zasedanie pravleniya TO IRGO, 3.02.1912. Protokol N 7 [Meeting of the Board 3.02.1912. Minutes N 7] // Izvestiya TO IRGO. 1912. T. 8. Vol. 3. P. 18-19. (In Russ.)

Zasedanie pravleniya TO IRGO, 11.11.1914. Protokol N 9 [Meeting of the Board 11.11.1914. Minutes N 9] // Izvestiya TO IRGO. 1916. T. 12. Vol. 2. P. 283-285. (In Russ.)

Ismailov E., Papava V. Centralnaya Evrasia: geopoliticheskoe pereosmislenie [Ismailov E., Papava V. Central Eurasia: Geopolitical Rethinking]. Stockholm: CA \& CC Press, 2010. 168 p. (In Russ.)

Karrer d'Ankoss E. Evraziyskaya imperiya: istoriya Rossiyskoy imperii s 1552 god do nashih dney [Carrère d'Ancoss E. Eurasian Empire: History of the Russian Empire from 1552 to the present day]. Moscow: ROSSPEN, 2010. 431 p. (In Russ.)

Kobzeva O.P., Zakirova M.H. Shelkoviy put v potoke istorii [Kobzeva O.P., Zakirova M.H. The Silk Road in the Flow of History]. Tashkent: Professional Solution, 2017. 283 p. (In Russ.)

Kotyukova T.V. «Musul'manskaya shkola i kak s ney borotsya»: impersky opyt v Tupkestane v nachale XX v. [Kotyukova T.V. «Muslim school and how to fight it»: imperial experience in Turkestan in the early twentieth century. ENOJ «History»]. 2014. N 4 (27). [Electronic resource]. URL: https://history.jes.su/s207987840000742-5-1 (date of acces: 15.01.2021).

Lavrov M.V. Turkestanskaya geografiya i istoriya kraya [Lavrov M.V. Turkestan geography and history of the region]. Moscow: Typo-Lit. 1916. 208 p. (In Russ.)

Miller A.I. Naciya, ili moguchestvo mifa [Miller A.I. The Nation, or the Power of Myth]. St. Petersburg: Eurasian University Press in St. Petersburg, 2016. 146 p. (In Russ.)

Ostroumov N.P. Konstantin Petrovich fon Kaufman, ustroitel Turkestanskogo kraya. 18771881 gg. [Ostroumov N.P. Konstantin Petrovich von Kaufman, the organizer of the Turkestan region. 1877-1881]. Tashkent, 1899. 286 p. (In Russ.)

Ostroumov N.P. Obshiy vzglyad na zadachyu russkoy administracii Turkestanskogo kraya k musul'manskomu naseleniyu [Ostroumov N.P. General view of the task of the Russian administration 
of Turkestan to the Muslim population]. Gosudarstvennyy arkhiv Respubliki Tatarstan (GA RT). F. 968. Op. 1. D. 43. 23 p. (In Russ.)

Obschee sobranie TO IRGO, 17.11.1906. Protokol N 2 [General Meeting 17.11. 1906. Minutes N 2] // Izvestiya TO IRGO. 1907. T. 7. P. 182-186. (In Russ.)

Obschee sobranie TO IRGO, 4.03.1914. Protokol N 1 [General Meeting 4.03.1914. Minutes N 1] // Izvestiya TO IRGO. 1916. T. 12. Vol. 2. P. 267-270. (In Russ.)

Obschee sobranie TO IRGO, 4.01.1915. Protokol N 11 [General Meeting 4.01.1915. Minutes N 11] // Izvestiya TO IRGO. 1916. T. 12. Vol. 2. P. 287-288. (In Russ.)

Otchet pravleniya TO IRGO 1914 g. [Report of the Board of the TO IRGO 1914] // Izvestiya TO IRGO. 1916. T. 12. Vol. 2. P. 293-301. (In Russ.)

Otchet o deyatel'nosti Sredneaziatskogo otdela Gosudarstvennogo russkogo geograficheskogo obshchestva (RGO) za vremya 1897 po 1927 gg. [Report on the activities of the Central Asian Section of the State RGO for the period from 1897 to 1927. Reports for 1926-1927 and for the time from 1897 to 1927 of the Central Asian Section of the State RGO]. Tashkent: Tipolit. 1927. P. 18-25. (In Russ.)

Perepiska N.P. Ostroumova i N.I. Il'minskogo po voprosam inorodcheskogo obrazovaniya [Correspondence between N.P. Ostroumov and N.I. Ilminsky on the issues of inorodic education]. // GA RT. F. 968. Op. 1. D. 16. 56 p. (In Russ.)

Pis'ma N.I. Il'minskogo k N.P. Ostroumovu (6 oktyabrya 1877-8 noyabrya 1890 gg.) [Letters of N.I. Ilminsky to N.P. Ostroumov (6 October 1877-8 November 1890)] // GA RT. F. 968. Op. 1. D. 78.89 p. (In Russ.)

Polojenie ob upravlenii Turkestanskim kraem [Regulations on the management of Turkestan region]. St. Petersburg: Gos. typ., 1886. 27 p. (In Russ.)

Programma shkoli dlya kreshenih inorodchev Vostochnoy Rossii [Program of a school for baptized foreigners of Eastern Russia. Kazan: Typo-litografia, 1898.] // GA RT. F. 968. Op. 1. D. 189. 9 p. (In Russ.)

Said E.W. Orientalism. Zapadnie koncepcii Vostoka [Said. E.W. Orientalism. Western Concepts of the East]. St. Petersburg: Russian World, 2016. 619 p. (In Russ.)

Schimmelpenninck van der Oye, David. Russkiy orientalism. Aziya v rossiyskoy soznanii ot epohi Petra Velikogo do Beloy emmigratsii [Schimmelpenninck van der Oye, David. Russian Orientalism: Asia in the Russian Mind from Peter the Great to the Emigration]. Moscow: Political Encyclopedia, 2019. 288 p. (In Russ.)

Tolz V. «Sobstvenniy Vostok Rossii»: Politika identichnosti i vostokovedenie v pozdneimperskoy i pannesovetskiy period [Tolz V. Russia's Own Orient: The Politics of Identity and Oriental Studies in the Late Imperial and Early Soviet Periods]. Moscow: New Literary Review, 2013. 336 p. (In Russ.)

Flygin Y.S. Nikolay Ostroumov: vostokoved, prosvetitel, letopisech epohi [Flygin Y.S. Nikolai Ostroumov: orientalist, educator, chronicler, epoch]. Tashkent: Turon zamin ziyo, 2016. 92 p. (In Russ.)

Khidoyatov G.A. Moya rodnaya istoriya [Khidoyatov G.A. My native history]. Tashkent, 1990. 303 p. (In Russ.)

Etkind A. Vnutrennyaya kolonizacija. Impersky opyt Rossii [Etkind A. Internal Colonization. Russia's Imperial Experience]. Moscow: New Literary Review, 2018. 448 p. (In Russ.)

Yavorsky I.L. Srednyaya Aziya. Kulturnie uspehi i zadachi v nei Rossii. Publichnaya lekciya, prochitannaya 19 iyulya 1893 goda v polzu popechitelstva o nedostatochnih studentah sego universiteta [Yavorsky I.L. Central Asia. Cultural Successes and Tasks of Russia in it. Public lecture delivered on July 19, 1893, for the benefit of the Trusteeship of Inadequate Students of this University]. Odessa: Printing House of the Odessa Military District, 1893. 38 p. (In Russ.) 